\title{
Public Sector Accounting and Accountability in Greece:
}

\author{
A Discussion \\ Anastasia Maggina, PhD (Corresponding author) \\ Business Consultant/Researcher \\ PAPAKOSTANDINOU 12 AVLONA ATTIKIS 19011, GREECE \\ Phone-FAX 01130 2295041643, anastasiamaggina@yahoo.gr
}

Received: May 25, 2011 Accepted: June 01, 2011 DOI: 10.5296/jpag.v1i1.685

\begin{abstract}
Public sector accounting and accountability have strong origins in ancient Greece in the framework of the democracy of Athens and the foreign aid later on. The organs of public accounting-management are stereotyped but transparency is still an open question. After the recommendations made by international Organizations(IMF, OECD etc.) and European Institutions(EU,ECB) many changes/innovations are on the way to restore confidence to citizens, the European partners and the international markets in an effort to get financing or restructure the terms of the very high national debt.
\end{abstract}

Keywords: Public sector accounting system, Public sector auditing, Budgeting, Public sector fundamentals, Trends, New policies. 


\section{Introduction}

The Greek system of public sector accounting has deep origins from Ancient Greece(Austin and Vidal-Naquet,1972) and strong historical ties with the rest of Europe and the USA in the framework of the foreign aid. However, it has not followed the recent reforms of some other Western European public sector accounting systems. These have an emphasis on value for money, including economy, efficiency and effectiveness. Incremental budgeting is still used, although zero based budgeting was introduced experimentally in the beginning of 1980's.However, it failed-so it was abandoned after the first year. As with most countries, the modified cash basis of accounting is still used for financial reporting.

The Greek public sector accounting system is governed by a law called the Public Accounting Code. The law and the 1975 Greek Constitution describe the budget system, related concepts and the management of public money. To fulfil its financial reporting responsibilities, the central government publishes several fiscal documents including the national budget, monthly statements of revenues and expenses, an annual balance sheet, the annual reports of revenues and expenditures, and the annual report of the Court of Audit. This final report suggests improvements to all aspects of the State's financial management. It is delivered to the President of the Parliament by the President of the Court of Audit. In addition, a summary is published in the Government Gazette.

The framework of the paper is organized as follows: Section 2 discusses the public sector accounting law, Section 3 describes the organs of public accounting management, Section 4 presents the budgeting system, Section 5 introduces budget execution and financial reporting, Section 6 discusses the approval and audit of expenditures, and the final section, Section 7 , concludes the paper.

\section{Public Sector Accounting Law}

The Public Accounting Code, legislative decree 321 of 1969, constitutes the fundamental financial law for Greece.It includes the following public accounting provisions:

- Allows wide flexibility for adaption to the fiscal conditions of the time

- Requires accurate execution of the budget, prompt collection of revenue and timely reporting of budget execution

- The decimal system of classifying revenues and expenses resulting in fiscal data comparable with figures from other countries

- Prohibits the payment of expenses from past fiscal years on the basis of ministerial decisions, this would require a special law for certain expenses to regularize payment

- Empowers the Minister of Economy and Finance to determine the percentage of the budget that can be spent each month by ministers or other budget holders, by category or group of expenses, according to the fiscal conditions of the country 
- Simplifies the process of payment of expenses, as long as the supporting documents are completed as required by the Minister of Economy and Finance, heads of services in ministries or local governments may authorise official orders rather than just the principal or the secondary officials in these institutions

- Introduces the innovation of clearance of unsettled payment orders at the end of the fiscal year with the issuance of promissory notes in the name of the assignees who can settle them any time until the completion of the statute of limitation without further authorisation

- Introduces the innovation of the preparation of the Annual Report and the Balance sheet of the State on the basis of the data submitted to the General Accounting Office of the State and by the Public Tax Services(Public Treasuries) and the changes announced by the Court of Audit until the end of August in the year of preparation

- Introduces the system of consolidated prepayments which may be authorised with a legislative decree or special law

- Modifies the provisions of the statute of limitation, it defines debts owed to the State in terms of Civil Law and the statute of limitation of claims against a member of the State applies even with an application to the Public Authority

- Provides for authorization by presidential decree, after a proposal of the responsible minister and the Minister of Economy and Finance(which constitute the Authorising Office in public entities), for audits of large public organizations(Kartsonas,1992,p. 4).

\section{Organs of Public Accounting-Management}

The Minister of Economy and Finance

The Minister of Economy and Finance is responsible for the general management of the budget and its execution and supervises the management of public money and the public property (Law 321/1969).

General Accounting Office of the State

The General Accounting Office has general responsibility for public accounting and reports to the Minister of Economy and Finance.It is responsible for:

- Management of public revenues and expenses along with the collection, analysis and processing of relevant data

- Preparation of the budget of the State, the annual report and the balance-sheet according to the Constitution and the Public Accounting Code

- Reviewing budget out-turn reports for all entities funded from the budget 
- Execution of the budget, both of revenues and expenses of the State

- Studying trends in public finance to recommend changes in fiscal policy by the Minister of Economy and Finance within the framework of general government policy

- Control of the economic management of the State along with the loan policy, the study of relevant issues and the service of the public debt

- Preparing general guidelines for the preparation and the execution of the budget of public entities and all decentralized services and the control of the management of funds and the property of these entities

- Regulation of capital circulation

- Reviewing financial reports from ministries and preparing reports to determine the actual level of expenses and revenues and the way that any budget deficit will be funded

- Supervision of the management of the public treasury, the application of the rules of Public Accounting to public entities and public utilities

- Regulating monthly salary payments

- Payment of pensions

- Management of subsidies for those who contribute to the economic development of the State

- Application of the necessary measures to ensure the sound management of the whole economy

- Publication each month in the Government Gazette of tables on the execution of the State budget so that this may be monitored by members of Parliament, financial analysts and other interested parties(Kartsonas,1992,p. 21).

The General Accounting Office receives data from the agencies it controls along with supporting documents; it registers this data using double-entry book keeping. It produces accounts of the budget and general accounts. The accounts of the budget indicate the course of the execution of the budget, and the general accounts indicate the funds of the State (monetary and nonmonetary).

As far as the analytical books, justifying documents registered to the books of the General Accounting Office of the State are the reports and other accounting data submitted by the public entities, the Export-Import Services and other specialized cahiers, the formal documents of the State or Banks or the orders of the movement of funds of the State to Public Tax Services issued by the General Accounting Office and signed by the Minister of Economy and Finance since they do not contain implementation of revenues and expenses.

Release of budgetary funds to public sector bodies are issued by the General Accounting Office and authorised by the Minister of Economy and Finance.This is because they do not involve implementation of budgetary revenues or expenses. 
As far as the general journal and the ledger, the monthly reports and the trial-balance of the entries of the subsidiary general journals and the ledgers, both for the budget accounts and the general accounts.

The accounts of the subsidiary and summary ledgers are balanced each month and a summarised report of the ledger accounts is published in the Government Gazette.

The Minister of Economy and Finance may authorise payments for expenses funded from the budget which are supported by money orders from the Bank of Greece. The Bank is responsible for submitting to the General Accounting Office, at the end of each month, a copy of the account "Ministry of Economy-Expenses account" along with relevant warrants which are submitted to the Court of Audit after they have been authorised.

A general record of public debt is kept at the General Accounting Office and the Central Bank. This includes an accurate register of all debts of each type. It indicates the capital outstanding, the time period of the debt, the calculation of interest, and the capital that is re-paid. At the year-end a general report of public debt is prepared which indicates its increase or decrease. This report is submitted to Parliament along with an analytical report. A copy of these documents and the annual accounts are also submitted to the Court of Audit for auditing.

The register of pensioners is kept at the General Accounting Office. It registers all pensions approved by law. All pensions are registered in the budget of the Minister of Economy and Finance.Each year they are submitted to the Court of Audit, with a special account of any increases or decreases in pensions, accompanied by supporting documents necessary for the recognition of new or amended pensions.

A special book of guarantees is kept by the General Accounting Office. It registers any payments made by public authorities due to such guarantees. Each year this book is submitted to the Court of Audit by the Minister of Economy and Finance with a special account of any guarantees paid, outstanding debts and the capital that has been paid back, along with all relevant supporting documents.

A committee oversees the work of the General Accounting Office and advices the Head of the Budget Department. This committee is chaired by the Head of the Budget Department and includes the heads of services supported by the budget and specialized accounting offices. Every three months the committee examines the budget outflows and recommends any measures that should be taken.

The Court of Audit

The Court of Audit is the Greek Supreme Audit Institution and is responsible for:

- The audit of all expenses of the State, local government organizations and other public entities which are under its control by special laws

- The preparation of a report to Parliament on the annual report of revenues and expenditures and the balance-sheet of the State

- Supervises the public accountable as far as the Public Accounting Law 
- Reports on the discharge of accountable for any loss or damage of documents of payments of any nature

- An audit of the accounts of public accountants, organizations of local government and other public entities

- Judges any doubts about the audit of the accounts of the accountable

- Providing an opinion on pensions laws and the point at which pensions are due to be paid

- Legal judgements on pension disputes

- Legal judgements on the responsibility of public employees for damages caused to the State by fraud or negligence.

- Around February of each year the Court of Audit examines reports from individual audits of revenues and expenses and adds their suggestions for any changes or improvements.

- A general annual report is prepared and discussed in a general meeting of the Court. It is then approved and submitted to the President of the State and Parliament and it is also published in the press (Court of Audit,1998,p. 22).

\section{Authorising Officers}

Authorising officers authorise official orders and other instruments giving rise to obligations for the State. They prepare money orders and send these to Public Accountants through the Authorising Office. Authorising officers are divided into principal and secondary authorising officers. Principal authorising officers are ministers and heads of local governments. Secondary authorising officers have budgets delegated to them by principal authorising officers to manage expenses in their areas of responsibility.

Principal authorising officers may be subject to political, civil and penal liabilities. Secondary authorising officers may have civil and administrative, and sometimes, penal liabilities.

Authorising Office

In each ministry or local government there is an Authorising Office. This office is responsible for the approval and clearance of all public orders, issuing money orders, managing special budgets and the producing the associated accounting reports.

Money orders, both ordinary and prepayment, are registered in chronological order in the general ledger. Money orders issued by secondary authorising officers are also recorded in the general ledger and each one is given a serial number. In addition, each month, receipts by the Public Tax Services are also recorded in the same ledger.

The book of approvals and payment orders registers per agency and code number of expenses of the Ministry

- The amount of the budget for the particular budget line for the ministry or local 
government

- The number and the date of the decision of the Minister of Economy and Finance to release a percentage of the budget to the ministry or local government

- The number and the date of the decision of the Authorising Officer along with the amount of the commitment undertaken(within the limit of the budgetary releases from the Ministry of Economy and Finance)

- The value of money orders, ordinary, and prepayment

- The payments acted with other titles in the corresponding credits and in the boundaries of liabilities and the monthly payments.

Other books maintained in the Authorising Office are:

- The book of the accounts of secondary authorising officers, the book of responsibilities of money orders of prepayments and temporary accounts,

- The book of prepayments of the Minister of Economy and Finance, and

- The payroll records for each proposed payment date for wages and salaries.

Money orders are audited every quarter. Reasons for the non-payment of money orders are ascertained and unsettled money orders are cancelled (Kartsonas,1992,p. 31).

Public Accountants

A Public Accountant is anyone who manages money, values or assets on behalf of the State even if he/she has no legal authorization and he/she is considered accountable by Law. Public accountants are State officials or those who work for public entities. They manage revenue collection and payments, imports and exports etc. They are supervised by the appropriate minister, the Minister of Economy and Finance and the Court of Audit(except for Public Accountants in the Ministry of National Defence who are only supervised by their Minister)(Kartsonas,1992,p. 43).

\section{Public Tax Services}

Public Tax Services collect State revenues also managing tax stamps, values and other items for sale. The collection of revenue from the account of other Public Tax Services and the payment of amounts to assignees sent by other Public Tax Services with money orders.

All revenues collected by Public Tax Services are deposited in the Bank of Greece under the account "BG-Collections and Payments".

Public Tax Services submit monthly statements of revenues collected for each budget code to the General Accounting Office. This includes the amounts that have been certified, cancelled, and collected during the month, without taking into account the electronic collection of tax. This document is then transmitted to the Information Centre of Fiscal Services which prepares the final monthly statement of revenues(Kartsonas,1992,p. 54). 


\section{Budgeting}

The Public Accounting Code in dealing with Greece's public budgeting provides the principles and rules for allocating public wealth, which includes tax revenues, borrowing, as well as assets. The law primarily covers central government, with a supplement dealing with other legal entities.

Up to 2007 the Greek budgeting system was based on incremental line items. Attention was focused primarily on the consideration of prior appropriations. Zero-base budgeting as it was mentioned above was introduced in the beginning of 1980's but it failed and was soon abandoned. A Planning, Programming, and Budgeting System (PPBS) has been introduced since 2008.

The deficit of the central government as a percentage of GDP and the national debt as a percentage of GDP in the last sixteen years are reported in the next Table 1:

Table 1:Deficit of Central Government and National Debt as a \% of GDP

\begin{tabular}{lcc}
\hline Year & $\begin{array}{c}\text { Deficit of Central Government } \\
\text { as a \% of GDP }\end{array}$ & $\begin{array}{c}\text { National Debt } \\
\text { as a \% of GDP }\end{array}$ \\
\hline 1996 & 9.8 & 111.3 \\
1997 & 6.1 & 108.3 \\
1998 & 4.4 & 105.5 \\
1999 & 3.7 & 104.6 \\
2000 & 2.5 & 118.0 \\
2001 & 1.9 & 119.0 \\
2002 & 3.5 & 118.2 \\
2003 & 4.1 & 109.9 \\
2004 & 7.7 & 109.3 \\
2005 & 5.9 & 107.9 \\
2006 & 4.4 & 95.9 \\
2007 & 4.1 & 94.8 \\
2008 & 4.4 & 109.6 \\
2009 & 14.3 & 127.0 \\
2010 & 9.9 & 148.0 \\
2011 (projection & 9.1 & 158.6 \\
\hline
\end{tabular}

Source: Budget of the State(2001,2002,2003,2004,2005,2006,2007,2008, 2009,2010,2011)

As far as the deficit of the central government the goal was to be reduced to $5 \%$ but it has not been achieved. This is due to: i) lower revenues, ii) increase of expenses, iii)increase of 
interest, iv)lower inflows from the European Union, v)lower inflows from social security organizations, vi)increase of national defence programs, and vii)adjustments in national accounts among others(Budget of the State,2010).This is considered a fiscal crisis. The point is that there are tremendous deficits in state hospitals, the local government and the state enterprises. Another main source of deficits is the very large number of public servants. On the other hand, financial crisis has as a result a negative growth and many economic indicators appear with unfavourable signs and trends.

According to the Public Accounting Code, the Minister of Economy and Finance is responsible for the Budget. Actually, nowadays the Ministry of Finance is responsible for the Budget of the State. Until 2009 there was one Ministry of Economy and Finance. After the elections of October 2009 the Ministry of Economy and Finance was separated into Ministry of Economy, Competitiveness and Shipping and the Ministry of Finance.

The fiscal year is the calendar year. The budget is prepared six months before the new fiscal year and about four months before its submission to Parliament (see Appendix).

On May 1 of each year the Minister of Economy and Finance issues an annual budget circular including directives and a timetable to all ministries and prefectures. Given the importance of the budget, political decision makers and heads of department all participate in preparing their budget proposals.

The overall budget is collated and prepared by the General Accounting Office. This Office prepares the government's budget proposals (for submission to Parliament) on the basis of proposals submitted by individual ministries.

The expenditure budget has an operating budget called the Ordinary Budget, and a capital budget called the Budget of Public Investments. It is prepared on the basis of requests by each agency, and considers such things as the number of employees, leasing and payments in foreign currency. The Ordinary Budget was in a traditional line-item form, with a distinct code number for the budgets for each ministry all over the past. The Budget of Public Investments is divided into sectors of economic activity.

The budgetary process relating to the Ordinary Budget is different from that relating to the Budget of Public Investments. In the latter case, anticipated sources of the Public Investment Program and the surplus of the Ordinary Budget are considered as sources of revenue. The Public Investment Budget is financed from both domestic sources(from domestic debt and from the surplus of the Ordinary Budget) and foreign sources (aid, loans, foreign credit).

All estimates developed by the General Accounting Office are summarized in budget tables and submitted to the Minister of Economy and Finance for final approval by the Ministerial Board. The Minister reviews the legality of proposed expenditures and the reasonableness of forecast. In consultation with other ministers and the Prime Minister, the Minister of Economy and Finance determines the final budget.

The Ministry of Economy and Finance is also responsible for overseeing the Budget of Public Investments. Every year the government sets the total for the Budget of Public Investments. 
This total is allocated to the ministries and different sectors. A schedule of capital projects is then forwarded to the General Accounting Office for inclusion in the overall national budget.

The Ministry of Economy and Finance also develops revenue projections. After the total amount of expenditures has been estimated, this ministry estimates the total revenues from various domestic and foreign sources for the budget period.

After the operating and capital budgets have been developed, an economic and fiscal report is prepared. In this report, past achievements are discussed and future goals are established. This Introductory Report covers all aspects of government activity, such as economic, social and cultural affairs and provides important background information for the annual budget. The General Budget of the State accompanied by the Introductory Report prepared by the Minister of Economy and Finance constitutes the Annual Budget of the State. This is submitted to and voted by Parliament, preferably one month before the beginning of the relevant fiscal year.

Once the Annual Budget has been submitted to Parliament, the Minister of Economy and Finance can make announcements but cannot make any changes to the document. It is made available to the public and is distributed to members of Parliament and is transmitted for consideration to the standing Parliamentary Committee of Economic Affairs. The head of this Committee, in consultation with the heads of parliamentary groups, determines a general speaker from each parliamentary group, special speakers from each parliamentary group (to introduce each subject and chapter of the budget) and one special speaker from the independent members of Parliament. Both general and special speakers submit their reports to the Committee within eight days of the first meeting and the budget is discussed in a maximum of three meetings. Reports prepared by the Committee and by the general and special speakers, are printed and distributed to the Parliament members at least three days before the beginning of the discussion in the Parliament Assembly.

A general discussion on the budget and on fiscal management takes place in a maximum of three meetings, with the Prime Minister, ministers, general speakers, heads of parties and special speakers as participants. A discussion of revenues in general and of expenditures for each group of ministries and for each category follows. No more than two meetings take place and all the above mentioned interested parties along with special speakers and registered members of Parliament are speakers. Members of Parliament vote separately on revenues and expenses for each ministry.

After the budget has been voted on by Parliament, it is affirmed by the President, published in the Government Gazette and becomes the law of the State. If Parliament does not approve the Budget, the government is required to resign, leading to parliamentary elections.

Exact dates for the Budget of the State are given in Appendix. The 2010 Budget of the State purports to restore the confidence of the citizens to the State and to restore the confidence of the country to European partners and the international markets as far as the data it reports and the policies it adopts.

Through the Budget of the State the following innovations are purported to be implemented: 
- A code of conduct for all agencies of the general Government

- Upgrading of the role of the Parliament during the submission and the discussion of the Budget of the State, the Annual Report and the Audit Report

- Adoption of a new audit system of the public management(instead of being focused on legality and regularity to be focused on 3 E's (economy, efficiency and effectiveness)

- Institutional independence of the Court of Audit and adoption of internal control systems and generally accepted international financial reporting standards(IFRS) by the agencies of the general government and also Generally Accepted Governmental Accounting Standards

- Application of the double-entry system and necessary financial reporting and disclosure by all agencies of the general government (Budget of the State, 2010;Hawkesworth et al.,2008).

\section{Budget Execution: Accounting and Financial Reporting}

During the financial year, the General Accounting Office is responsible for preparing monthly statements of budget execution. These statements summarize the status of budget execution and the status of the accounts financed by the Budget. For example, the revenue section of the monthly statements reports revenues recognized during a particular month as well year-to-date figures, both for individual revenue sources and total revenues. Similarly, monthly and year-to-date expenditure figures are reported for each type of expenditure as well as in total. The monthly statements do not report obligations, but only cash inflows and cash outflows. They are published each month in a special issue of the Government Gazette. Copies are sent to the Minister of Economy and Finance, the Court of Audit and to the Public Tax Services.

Two financial statements are prepared after the end of the financial year. These are the balance sheet and an annual report of budget execution. The balance sheet reports the status of the State treasury's financial assets and liabilities. It does not include tangible or intangible assets, inventories nor prepaid expenses. Prior to 1993 pension costs were accounted for on a "pay as you go" basis. Since then pension liabilities have been reported in the balance sheet and so the Government debt appears to have increased by an amount equal to these liabilities. Detailed disclosures are made on debt issuance. Finally, the equity section consists of net capital and the cumulative results of operations.

After some recommendations made by International Organizations(i.e. IMF, OECD etc.) and European Institutions(EU,ECB) modernization of accounting procedures in the Central Government has been on the way Accrual accounting has been directed but revenues and expenses will continue to be considered as cash inflows and outflows, thus far, modified cash accounting is the operating accounting procedure. Toward this direction the Information System of Fiscal Policy is structured for the General Accounting Office of the Ministry of Finance. Finally, two accounting systems will operate: 
1) Cash accounting for the implementation o the Budget of the State, and

2) Modified cash accounting that will provide the background to prepare accounting information through financial statements.

The financial statements of the Central Government are currently the following:

- Statement of financial position

- Statement of financial performance

- Statement of cash flows

- Statement of changes of net position of the citizens.

\section{Audit of Public Money}

It is widely accepted that public finances should be audited each year by an audit institution which is, ideally, independent of the executive branch of the State. Greece has a judicial audit function which is adopted in the constitution.

The Greek Court of Audit is responsible for the following:

1) Auditing the finances of central government, local governments and other entities under its jurisdiction,

2) Auditing the accounts of public accountants and providing judgements relating to these accounts,

3) Reporting to Parliament on the annual report and the balance sheet of the State,

4) Providing an opinion on the annual statement on State pensions,

5) Seeking recourse or appeal against the actions of ministers, or of any other organs of public administration, local governments or other entities (Authorising Officers),

6) Providing judgements concerning the responsibility of public servants for any actions to the detriment of the State caused by fraud or negligence,

7) To make judgements on discrepancies relating to pension appropriations as they are specified by law(Themeli,1983).

Ministers do not report to the Court of Audit as they are political office holders.

The Greek Court of Audit was established in 1833.Its two main responsibilities have been first for the audit of the accounts of the Public Accountants and the Authorising Officers. Second, it has reported to Parliament through its annual report on the legitimate and honest management of public money as it is performed by the executive.

According to the provisions of the legislative decree 1265/1972, which refers to public audit, a formal audit consists of the audit of both:

a) The legitimacy of all financial transactions in the sense that "there are legally provided 
appropriations” or that they have followed the budget approved by the Parliament,

b) The regularity of each transaction in that "the provisions of the Public Accounting Code and of any other relevant law, decree or bylaw have been followed”.

The provisions of the Public Accounting Code (legislative decrees 321/1969 and 496/1974) clearly describe the principle of specificity of appropriations. This requires all transactions to be associated with a specific line in the approved budget.

According to legislative decree 1265/1972, the judicial audit of public money is both preventive and suppressive(post audit). The preventive audit of expenditure constitutes the most significant part of the audit of public money. The Court of Audit, including its President and other judges, examines the relevant money orders (regular warrants and prepayments) and so agrees on the legality of the Money Orders. In particular, the President undertakes the audit of expenditures authorised by ministers and the other judges audit expenditures authorised by other Authorising Officers. The Court then audits the legitimacy and regularity of actual payments or receipts managed by the Public Accountants.

\section{Conclusions}

The origins of accounting for public money in Europe started in Ancient Greece. The circulation of public money passes over many organs with a risk in money abuse and mismanagement. Since the democracy of Athens in Ancient Greece the system of public accounting and audit has emphasised the need for legality and regularity. Recently and after the recommendations made by international Organizations(IMF, OECD etc.) and European Institutions(EU,ECB) public accounting and management have been identified as a system that purports to economy, efficiency, effectiveness, transparency and trustworthiness. Financial reporting has been restructured with financial statements developed in the same vein as in the private sector. What is suggested for further research is the inclusion of notes to the financial statements, that is, the assumptions and accounting principles used since they are necessary to follow the financial statements. Accompanying detailed notes will contribute to transparency and financial disclosure. On the other hand, it remains to be seen if the recommendations as far as the budget preparation and execution mainly focused on Planning, Programming, Budgeting System will provide meaningful results in the framework of the Stability Plan of the Greek economy and the Support Mechanism with European Union, European Central Bank, and the IMF inclusive. That is if the PPBS will be fruitful apart from the cut of public expenditures and the collection of higher revenues as decided in a political will.

\section{References}

Austin, M. M. and P. Vidal-Naquet (1972)"Economic and Social History of Ancient Greece:An Introduction”Berkeley,University of California Press

Budget of the State,2010,Athens,Greece

Court of Audit(1998)Rules and Provisions about the Court of Audit, National Publishing Organization,Athens 
Jones,N.(1987)"Public Organization of Ancient Greece: A Documentary Study”,Philadelphia:American Philosophical Society

Jones,R. and M.Pendlebury(1992)“Public Sector Accounting”,Pitman Publ.,London

Hawkesworth,I.;D.Bergvall;R.Emery and J.Wehner(2008)”Budgeting in Greece”,OECD Journal of Budgeting, Vol. 3,pp. 2-50

Kartsonas,G.(1992)“Public Accounting Law”, Sakkoulas Publ.,Athens

MacDowell,M.D.(1978)“The Law of Classical Athens”, London:Thames and Hudson Ltd.

Maggina,A.(1995)“Accounting and Accountability in the Greek Public Sector”, Workshop on Accounting, Accountability and the New European Public Sector,EIASM,Finland

Maggina,A.(1996)“Government Accounting:Political Institutions or a Polity”,Research in Governmental and Non-profit Accounting,Vol. 9,pp. 275-282

Petrohilos,M.K.(1970)“The Court of Audit in Greece”,Public Sector Accounting Publishing Organization

Sarantopoulos,C.(1980)"'The Organization of the Audit of Public Money, and the Court of Audit”,Athens, Court of Audit Publishing Office

Sarantopoulos,C.(1978)"The Judicial Audit of Public Money",Athens, Court of Audit Publishing Office

Themeli,N.(1983)“The Court of Audit in Greece: One Hundred and Fifty Years”,Athens, National Publishing Organization

\title{
Appendix
}

\section{Appendix 1. Time-table for Preparation and Approval of the Budget}

\author{
May 1 of each year \\ Issuance and circulation of a circular to prepare the \\ Budget of each Ministry and region \\ End of June \\ Proposals for the Budget submitted to Department 20 \\ of the General Accounting Office \\ End of June to End \\ Review of the proposals by the Department 20 and \\ of September \\ prepare estimates of revenues and expenses. \\ Discussions between Dept. 20 and representatives of \\ ministries and determination of final magnitudes \\ Mid of September \\ The Minister of Finance reports the final numbers of \\ the estimates of closing the fiscal year and forecasts \\ for the Budget of the next year to be approved by the \\ Prime Minister and to be included in the Draft of the
}


First Monday of

October

October

At least 40 days

before the end of

the year

November-December

End of December
Budget of the State

Draft is submitted to the Committee of Economic

Affairs of the Parliament

Discussions about the Draft by the Committee of

Economic Affairs of the Parliament in three meetings

The final Draft of the budget of the State is prepared

by the Dept. 20 after the proposals and remarks made

by the Committee of Economic Affairs

The Minister of Finance submits the Final Draft of

the Budget of the State to the Parliament for discussion

The Final Draft of the Budget of the State is

discussed by the Committee of Economic Affairs of

the Parliament

The Final Draft of the Budget of the State is

discussed by all members of the Parliament in five

meetings and approval of the Budget is made in the

midnight of the fifth meeting. 